\title{
THE 'MASSERIA ROTA’ IN NAPLES (ITALY). A VERNACULAR HERITAGE TO PRESERVE
}

\author{
R. Amore ${ }^{1}$, L. Veronese ${ }^{1, *}$ \\ ${ }^{1}$ Department of Architecture, University of Naples Federico II, Italy - (raffaele.amore, luigi.veronese2)@unina.it
}

Commission II - WG II/8

KEY WORDS: Vernacular architecture, Restoration, Naples, Masseria Rota, Cercola

\begin{abstract}
:
The 'Masseria Rota' in Cercola, near Naples, is one of the best-preserved examples of the important vernacular architectural heritage of the Vesuvian area. Built in the 17th century upon more ancient pre-existences, the farm is an extraordinary example of the construction capabilities typical of the Neapolitan area and the dual vocation, productive and residential of the Vesuvian 'masserie'. The production area for slaughter and winemaking - located on the basement floor and still in good condition - coexists with the residential part with a sober decorative apparatus, enriched by the nineteenth-century transformations. Its planimetric U-shaped layout denounces a development for subsequent integrations that is also evident from the mensiochronological analysis of the walls. Unfortunately, despite the its indisputable historical, architectural and documentary value, the 'Masseria Rota' is in a serious state of abandonment, suffocated by contemporary buildings often devoid of specific values. The contribution to be presented illustrates the results of a teaching experiment that aims to propose methodological guidelines for the drafting of a restoration project aware and respectful of the identity of the aforementioned 'Masseria', and intends to provide a contribution of knowledge for the preservation and enhancement of a vernacular building heritage present on the slopes of Vesuvius, guiltily forgotten and abandoned in recent decades, which, instead, represents one of the most interesting and important of the settlement and construction modes of a territory inhabited since antiquity - despite the cyclical destructions caused by the volcanic activity of Vesuvius - for its environmental and landscape characteristics.
\end{abstract}

\section{METHODOLOGICAL PREMISE}

This contribution is the result of ongoing studies in the field of teaching and applied research of the Authors in the Department of Architecture of the University of Naples, dedicated to knowledge and historical-urban interpretation, technical-constructive and historical-architectural of the building heritage of the Neapolitan area, with special reference to the rural architecture of the Vesuvian area. The study as a whole intends to investigate the system of villas-farms of the seventeenth and eighteenth centuries built in the fertile territory of Vesuvius, to outline possible and desirable restoration and enhancement interventions, which know how to confront the 'palinsesto' of signs and memories guarded by such artifacts. The research work is based on the knowledge that the examination and classification of historical-archival and iconographic documentation are extraordinary tools of investigation and knowledge that find their completion by combining with the results of the direct and multidisciplinary examination of the physical consistency of the architectural artifact. The metric survey and the identification of materials and construction's typologies used to build an ancient architectural artefact allow, in fact, to relate and compare the results of iconographic and documentary studies with the structural stratigraphy of the elements of the architectural construction, the wall weavings, the materials used, the construction types and, therefore, allow to add new tiles to the mosaic of knowledge.The study of the building in its different aspects, metric-dimensional, historical, type-morphological, formal and even pathological, linked to the phenomena of static failure and degradation, makes possible an increase in the perception and interpretation of values of the building, in a continuous passage of scale, from the physical reality of the object to the historical-documentary and interpretive data, allowing to grasp the architectural, structural, decorative and

\footnotetext{
* Corresponding author

1 In the aftermath of the devastating eruption, Tito appointed two magistrates - curators restituendae Campaniae - to oversee the works
}

formal values that characterize each ancient building, through the reading of the traces that history has imprinted in its material. For this reason, the ongoing work is based on the execution of direct investigations of the material consistency of historical architectural artefacts, according to an 'archaeological' approach, with the aim of integrating historical research and achieving a contextual, interdisciplinary and polysemantic interpretation of architectural heritage. The current consistency of 'Masseria Rota' in Cercola, in the province of Naples, lends itself well to the field application of such research goals. The contribution that is presented considers the first developments of the analyses and studies conducted and traces the basis for the necessary project developments.

\section{THE TERRITORY ON THE SLOPES OF VESUVIUS}

\subsection{Between roman time and Bourbon's reign}

The area between the current municipalities of Cercola, Pollena Trocchia, Massa di Somma and San Sebastiano al Vesuvius, in the province of Naples, was the western flap of the caldera of Mount Somma. In ancient times it constituted the margin between the territories of Neapolis and Herculaneum and bordered to the east with the territory of Nola. Recent studies on archaeological evidence unearthed in the area in recent decades (De Simone et al., 2012; De Simone et al., 13; De Simone, 2010) testify how, after the catastrophic eruption of 79 A.D. that buried the cities of Pompeii, Herculaneum and Oplonti, the process of reconstruction ${ }^{1}$ of the Vesuvian area was in more than advanced phase already at the beginning of the 3rd century. The Roman authorities committed considerable resources both to the restoration of public monuments damaged by the telluric phenomena that had accompanied the eruption, and to the recovery of the countryside, in order to redefine the land limits 


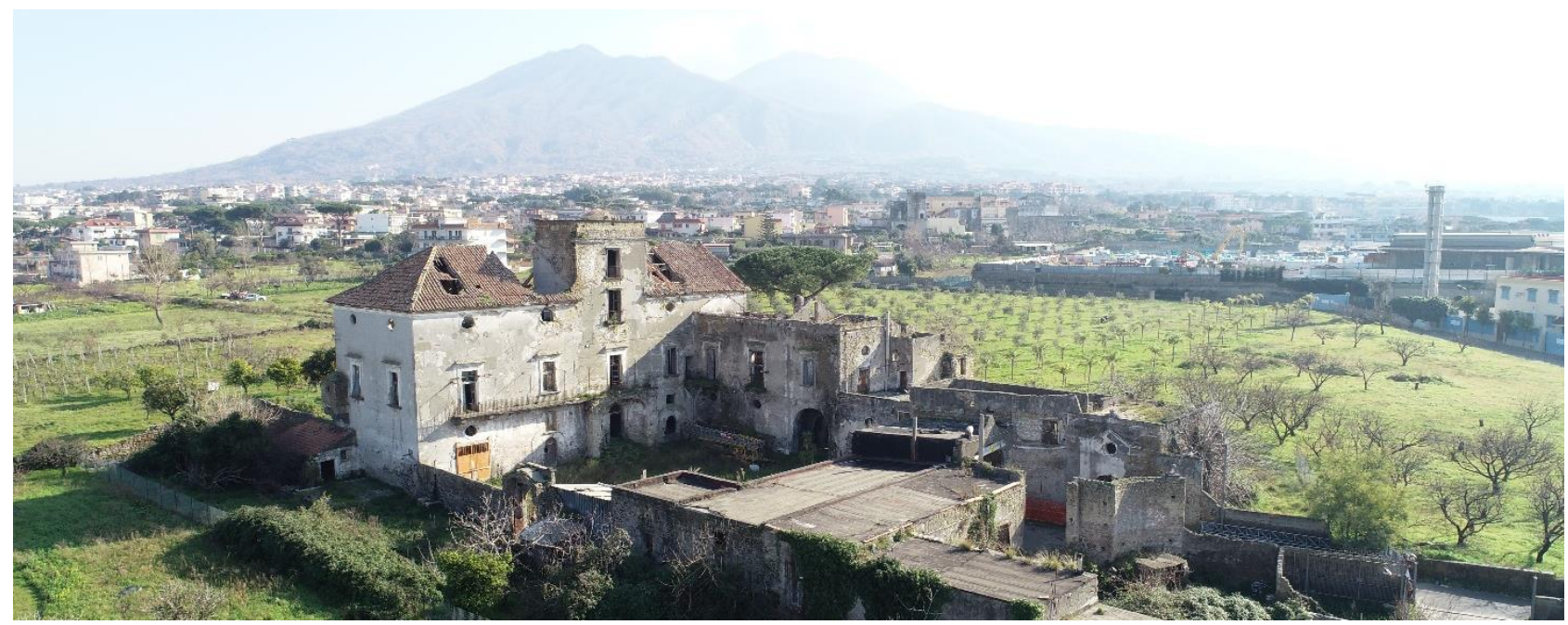

Figure 1. An aerial view of Masseria Rota. (Marco Facchini, M_Lab, Department of Architecture, Naples, 2020).

and allow a resumption of the agricultural production. The subsequent eruption of 472 caused a second major upheaval in the area under consideration, causing a drastic decrease in arable areas. From the early Middle Ages, when, however, the eruptive activities of Vesuvius were not particularly relevant, the Vesuvian territories were reurbanized according to settlementary models characterized by small urban centers and agricultural farms (Soricelli, 2001). In the Angioinian period, first, and Aragonese, then, the area immediately close to the 'Antic Strada per le Calabrie', already restored in the Adrianean era, was affected by the construction of aristocratic mansions ${ }^{2}$. Subsequently, the large feudal families of the southern regions of the Kingdom, forced by Viceroy Don Pedro of Toledo to a real exodus to Naples, invested part of their wealth in the Vesuvian agricultural areas, creating villas, palaces and agricultural residences, with the consequent economic revival of the whole area. This phenomenon suffered a new abrupt interruption with the terrible eruption of 1631 that destroyed much of the cultivated areas of the southern side of Vesuvius. Nevertheless, the population soon returned to the destroyed areas, rebuilding the houses and resuming a slow but continuous work of agricultural recolonization. Charles of Bourbon's decision to build in Portici - shortly after his arrival in Naples as king - a new Royal Site (Amore, 2017, p. 376-384) and the almost contemporary archaeological discoveries of Herculaneum (1738) and Pompeii (1748), produced an acceleration of this process of urbanization, which in the next fifty years took on new characteristics compared to the past, testifying to the value and natural and significance that had taken over the Vesuvian coast between Naples and Torre del Greco. Throughout the 18th century, therefore, the entire area between Vesuvius and the sea was affected by intense construction activity and agricultural transformation of the territory. Pre-existing structures were expanded, renovated, as in the case of the 'Sito Reale of Portici',others built ex novo with the contribution of the best architects, painters, decorators of the time to satisfy to the taste and needs of the nobility that preferred to live for long months a year away from the city, in a climate of tranquility and in contexts of high landscape value, but also to exert control over the farmers who worked on their farms, from the particularly fertile soils ${ }^{3}$ (Marino, 2017). In relation to the typological and formal characteristics of the 'Ville vesuviane' system, Cesare de Seta proposed an interesting and shared classification in two groups. The first belong to the villas in which the productive function prevails, real farms in which the owner stayed mainly in the summer periods also to control the management of the related agricultural fund; often isolated, are located on the slopes of the volcano, away from the sea. Around a courtyard - in direct communication with the land cultivated in vineyards and orchards - there are several factory bodies, the residential one, multi-storey and often with sophisticated architectural forms, and those of service, at a single level. Usually, next to the main entrance of the villa or the access portal was built a chapel, accessible by the local farmers. The second group, on the other hand, belongs to the 'villas of delight', the result of the fusion of the type of farm with the stately palace. They are generally located near the coastal area, downstream or upstream of the " Regia strada per le Calabrie'; if upstream, the windows of the road side look in the direction of the sea, while the interior ones towards Vesuvius; if downstream, on the other hand, the interior facades are facing the sea, the eternal ones towards the volcano (De Seta et al. 1980, p. 25-29).

\subsection{La 'Masseria Rota' in historical maps}

On sheet 14 of the Atlante geografico del Regno di Napoli of Rizzi Zannoni is represented - passed the area of Piazza Mercato in Naples - the route of the 'Antica Strada per le Calabrie' (in blue in Figure 2), which crosses the ancient village of San Giovanni a Teduccio, Portici and Resina, continuing towards Torre del Greco. Perpendicular to this route, immediately before and after the urban conglomerate of San Giovanni a Teduccio, two roads set off, climbing - more or less parallel - towards the slopes of Vesuvius, to be reunited in the village of St. Anastasia. The first road (in green in Figure 2) crossed the villages of Barra and Ponticelli, first, and Cercola, then; second street (in red in Figure 2) passed the village of St. Jorio (now San Giorgio a Cremano), directed towards the towns of San Sebastiano, Massa and Pollena. The entire area is dotted with farms belonging to noble families: near 'la Tufarella' are represented two groups of three building volumes, which could correspond to those of the Casa del Rota' and the 'Casino Figliola'. These farms are laboriously documented in sheet 14 of Mappa topografica della città di Napoli e de' suoi contorni di Giovanni Carafa duca di Noja e

\footnotetext{
Alfonso of Aragon often stayed at Torre del Greco where he built a house for his favorite lover Lucrezia d'Alagno. Bernardino Martirano, secretary of the Kingdom of Naples around 1520 had a sumptuous villa built along the 'Antica via delle Calabrie', called 'Leucopetra', where Emperor Charles V was a guest, returning from the 1535 expedition to Tunis.
} 


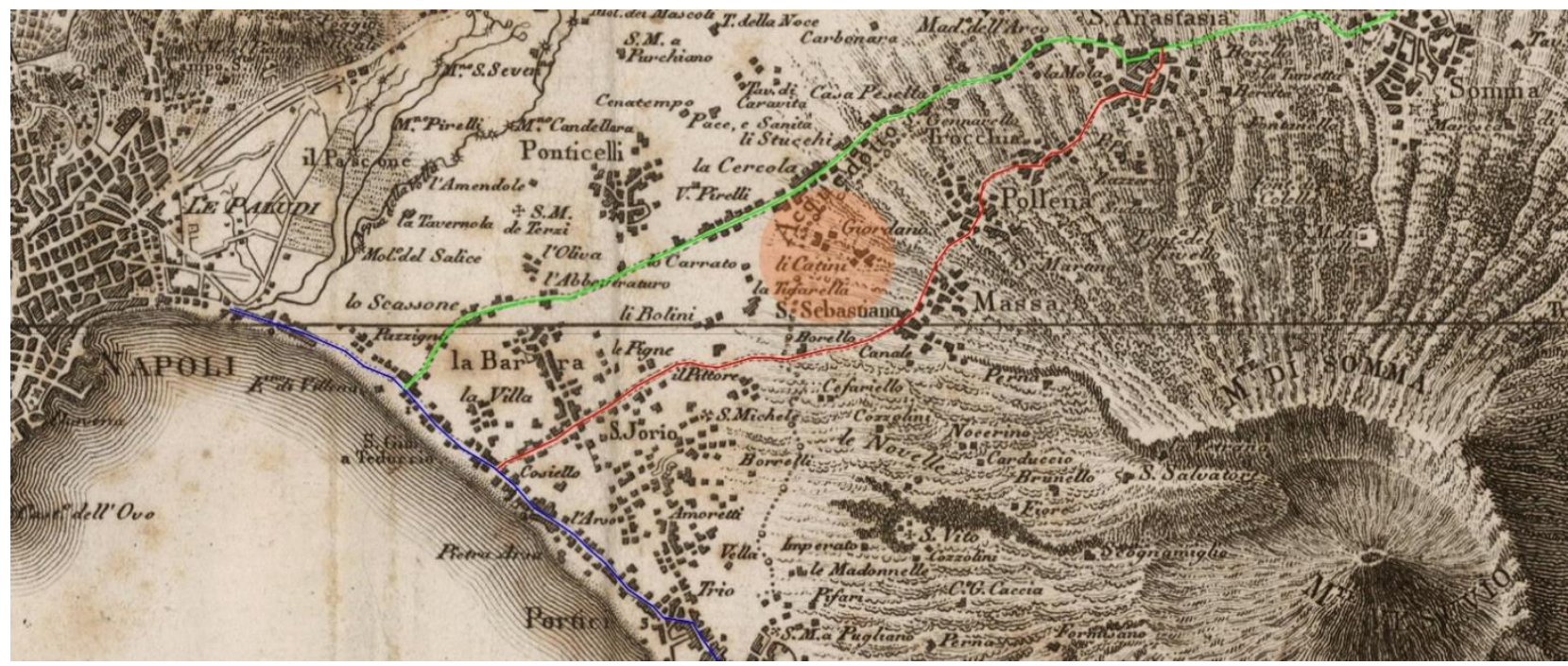

Figure 2. Atlante geografico del Regno di Napoli delineato per ordine di Ferdinando IV re delle Due Sicilie \& C. \& C. da Gio. Antonio Rizzi-Zannoni geografo di Sua Maestà e terminato nel 1808. Naples, s.n., 1788-1812, detail of the paper 14.

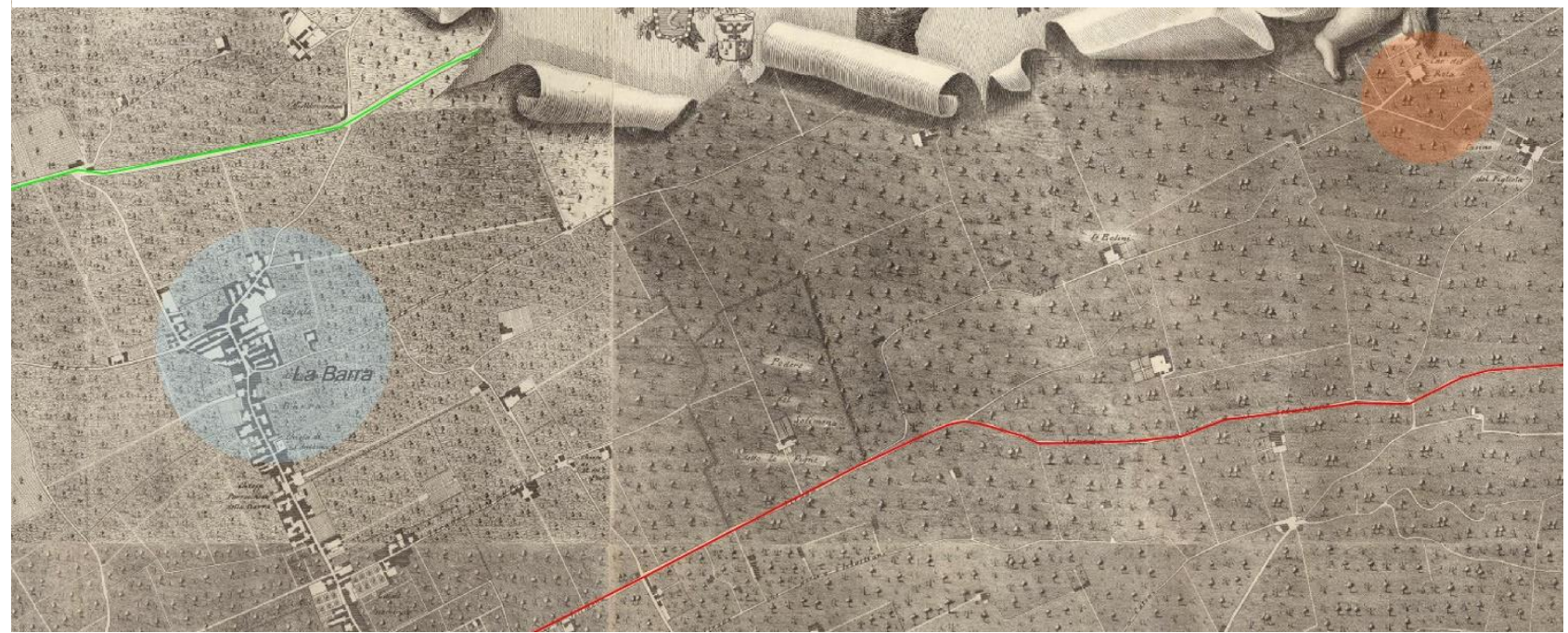

Figure 3. Mappa topografica della città di Napoli e de' suoi contorni di Giovanni Carafa duca di Noja e Niccolò Carletti, published in the1775, details of paper 14.

The plan (35 papers), began in 1750 and ended 25 years later, constitutes a fundamental iconographic document, not only for the description of the city, but also for the use of the most up-todate methods of the eighteenth-century topographical science. For the first time Naples is represented with its vast suburban territories that go from Resina to Poggioreale in the north, and Bagnoli and Nisida in the east. The long legend of 580 entries enriches the informations.

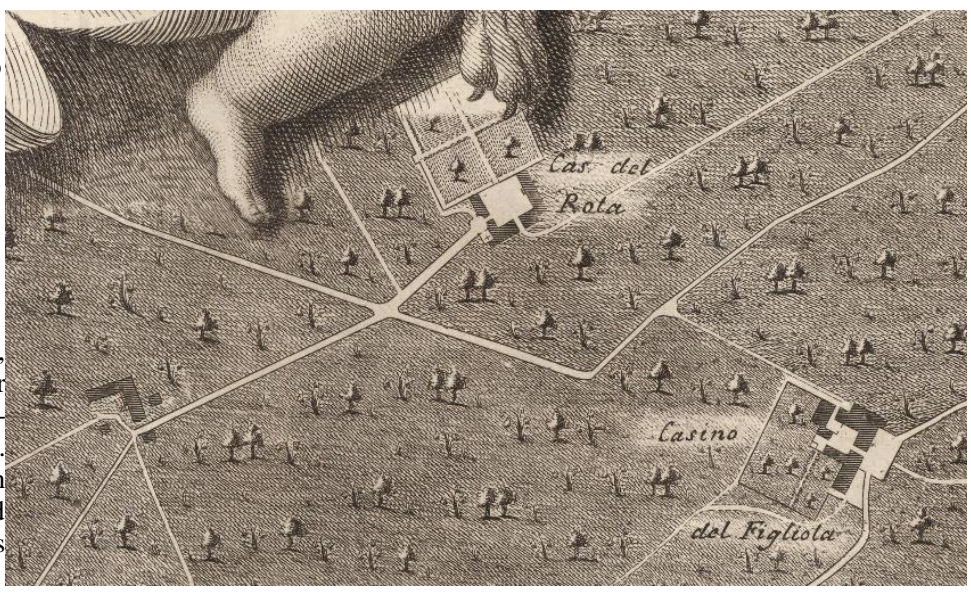

Niccolò Carletti, pubblicata nel 1775. In this map, in which the system of interpoderal roads at the service of the different farms is well delineated, the 'Casale' is represented in a very precise way. During the Nineteenth century, following also the Vesuvian eruptions in 1855 and 1868, which destroyed the city center of Massa, the entire area upstream 'Masseria Rota' underwent important transformations, concerning the creation of new road axes and the development of the newborn municipality of Cercola. Identically, even the downstream area, close to 'Antica
Strada per le Calabrie', underwent considerable changes: the construction of the Naples-Portici railway line ordered by the Bourbons and the installation of the first industrial complexes in the Vigliena area started an urbanization process which, added to the intense building development of the post-war period, has strongly altered the original relationships between the built environment and nature. Since the sixties of the twentieth century, despite the danger posed by the presence of Vesuvius, in all Vesuvian municipalities has been realized a massive building 


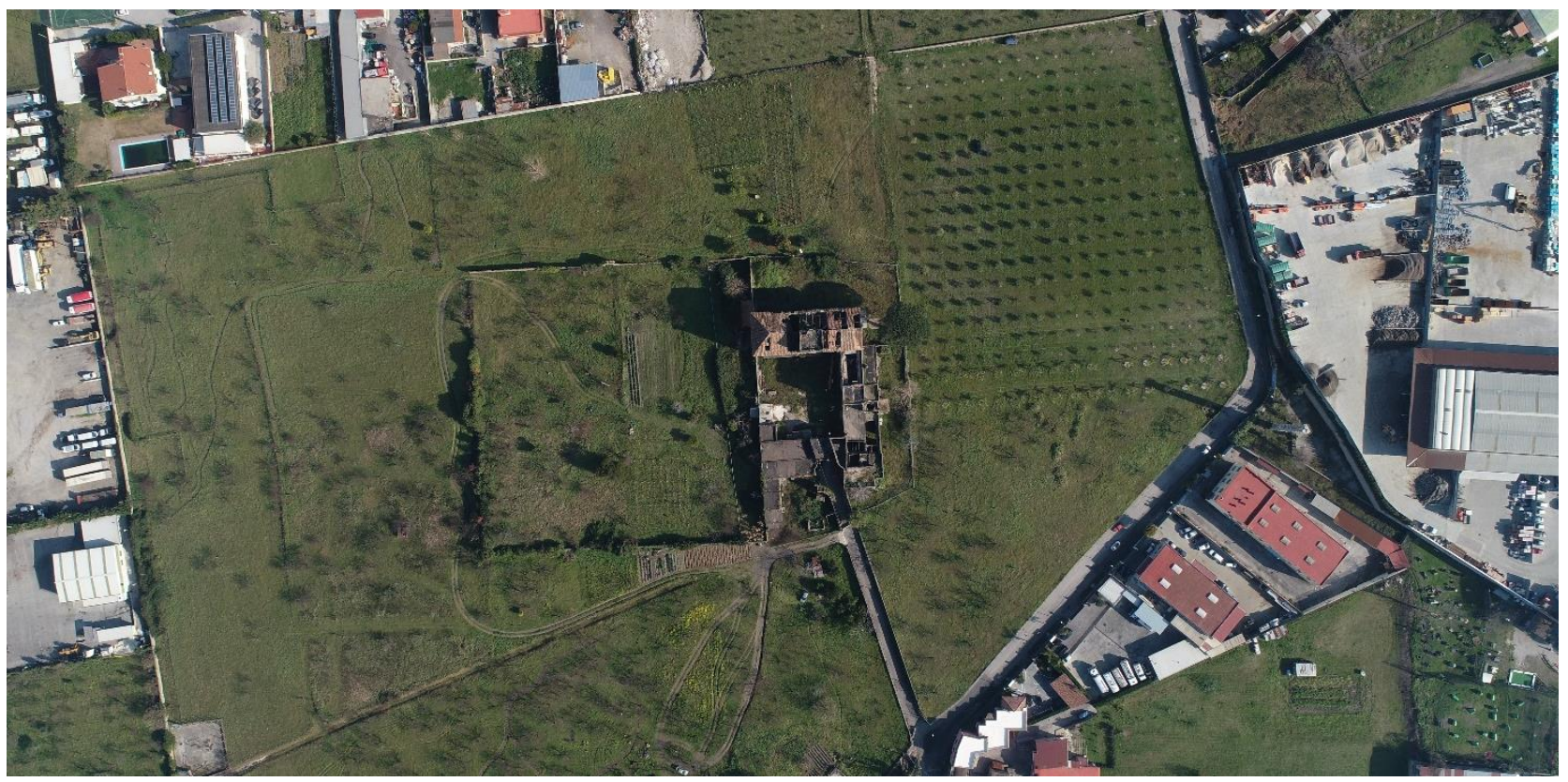

Figure 4. An aerial view of 'Masseria Rota' (M. Facchini, 2020).

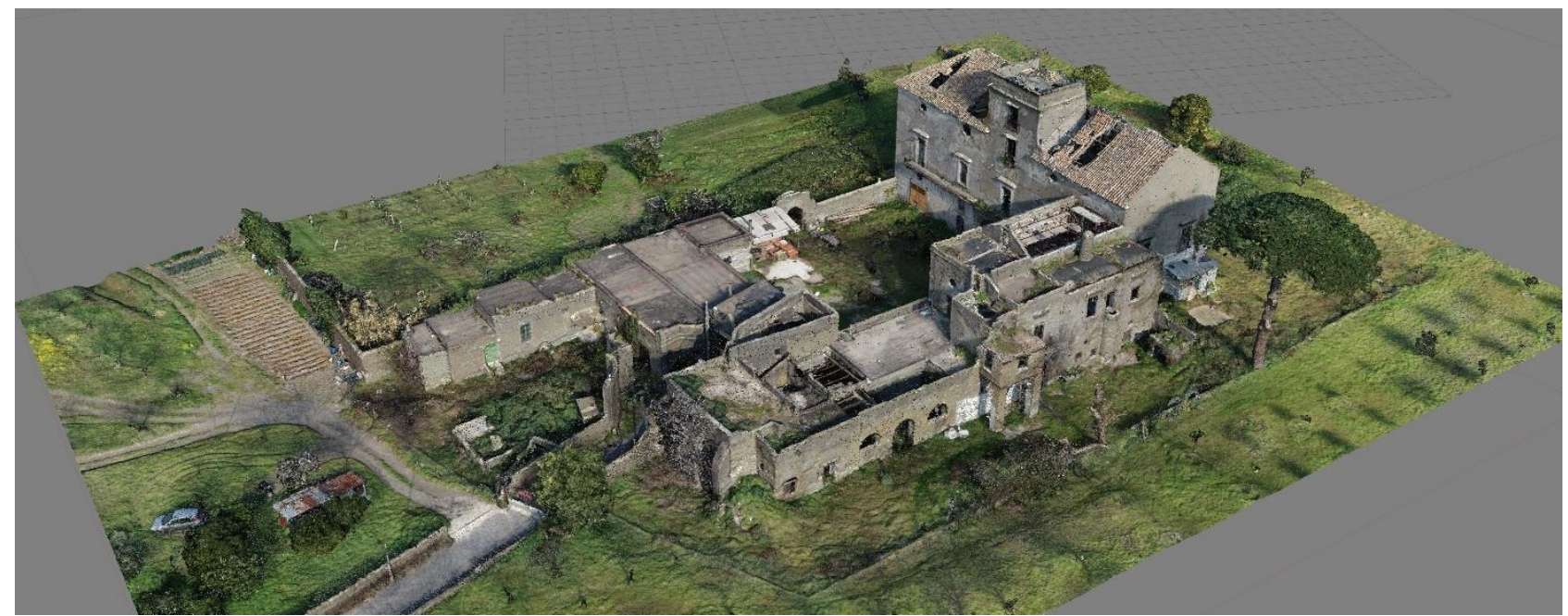

Figure 5. Image of 3D survey obtained by photomodeling being processed (M. Facchini, 2020).

expansion without quality that seriously compromised the historical and environmental values of the area. Many of the ancient farms in the area, as well as important Vesuvian villas, have been deprived of their land and gardens and not infrequently in a precarious state of conservation, surrounded by modern buildings. 'Masseria Rota' has partially survived this fate. Although it is in a condition of severe degradation due to decades of neglect and inactivity, it still retains a good part of the agricultural areas of relevance and, therefore, the deep link between the architectural structure and its environmental context is still perceptible today. The current consistency of the masseria is - excluding some recent superfetations - that represents in the aforementioned plan of the Duca di Noja in 1775. At the beginning of the eighteenth century, in 1704, the daughter Veneranda of the marquis Sergio Sersale - originally owner of the farm and the annexed land - married Bartolomeo Rota, nobleman from Cremona, who became Marquis of Colletorto; he commissioned important works to expand the casino, transforming it into a rustic villa. Currently the masseria has a 'U' shape in plan, with the open side facing a garden bordered by a wall. The simplicity of the installation is partially contradicted by the different height and intended use of the existing buildings.
The central rectangular courtyard was accessed from two entrances: the first was located to the south-west, and was placed at the end of a road that branched off from the road coming from Naples, whose axis does not coincide with the facade, determining an atypical misalignment between the entrance direction and the facade of the entrance building; the other, on the side facade facing south-east, was instead served by a path that led to the farmland. It should be immediately pointed out that the position of the villa does not coincide with any of the road axes represented in the aforementioned map of the Duca di Noja, and therefore it is conceivable that the access road on the southwest front was built in conjunction with the eighteenth-century restructuring: this it is also supported by the compositional expedient adopted for the reconfiguration of this front, i.e. that of creating an entrance exedra and a hallway with a crooked geometry, useful for prospectively directing those who accessed the masseria from that entrance towards the center of the building placed to close the courtyard on the opposite side, intended for residence. The small church dedicated to the Immaculate Conception develops sideways to the exedra, with the entrance rotated 90 degrees with respect to the access to the villa. It constitutes the head of the building facing south-east, whose 


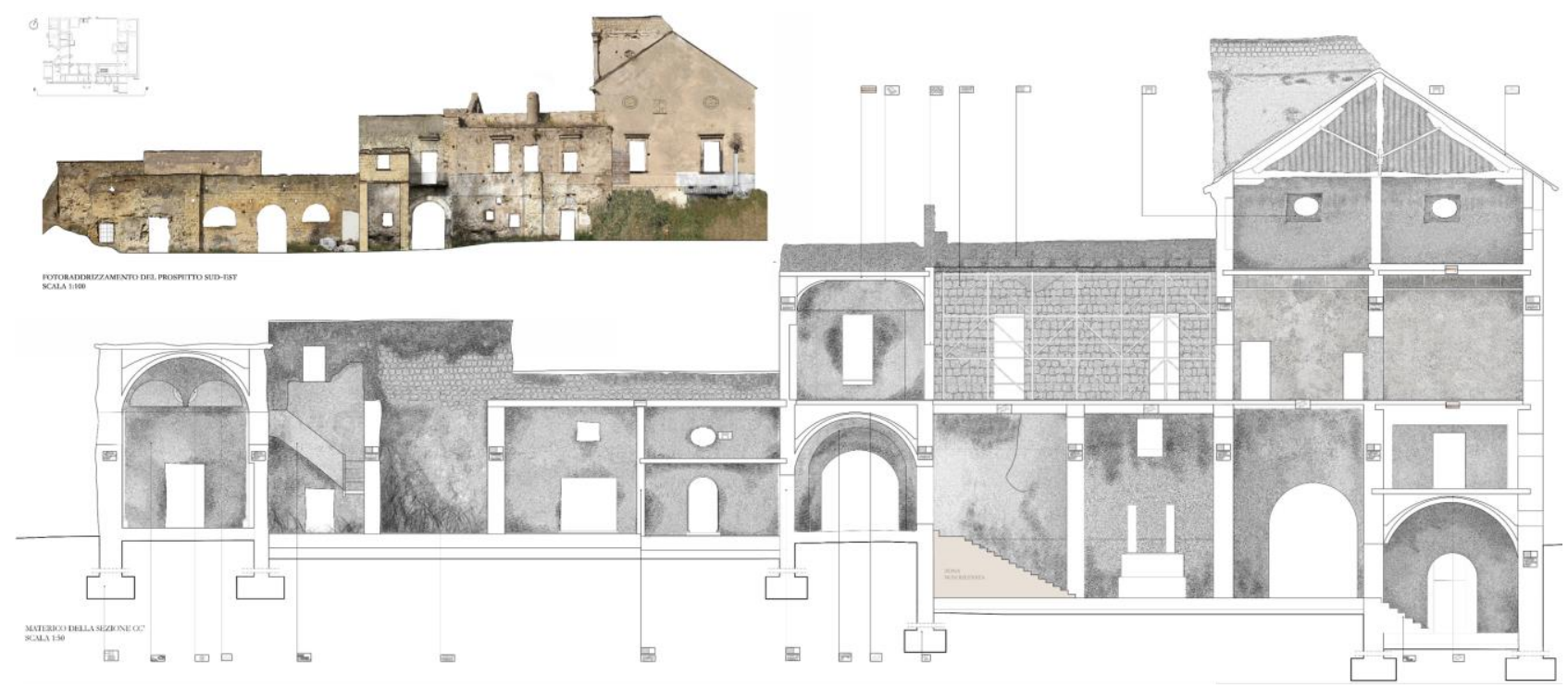

Figure 6. F. Amoddio, C. Barone, M. Bosone, F. Di Lorenzo, M. Franceschetti, Degree thesis in Architecture 5 UE, University of studies of Naples Federico II, A.Y. 2018-2019, tutor. Prof. arch. Renata Picone.

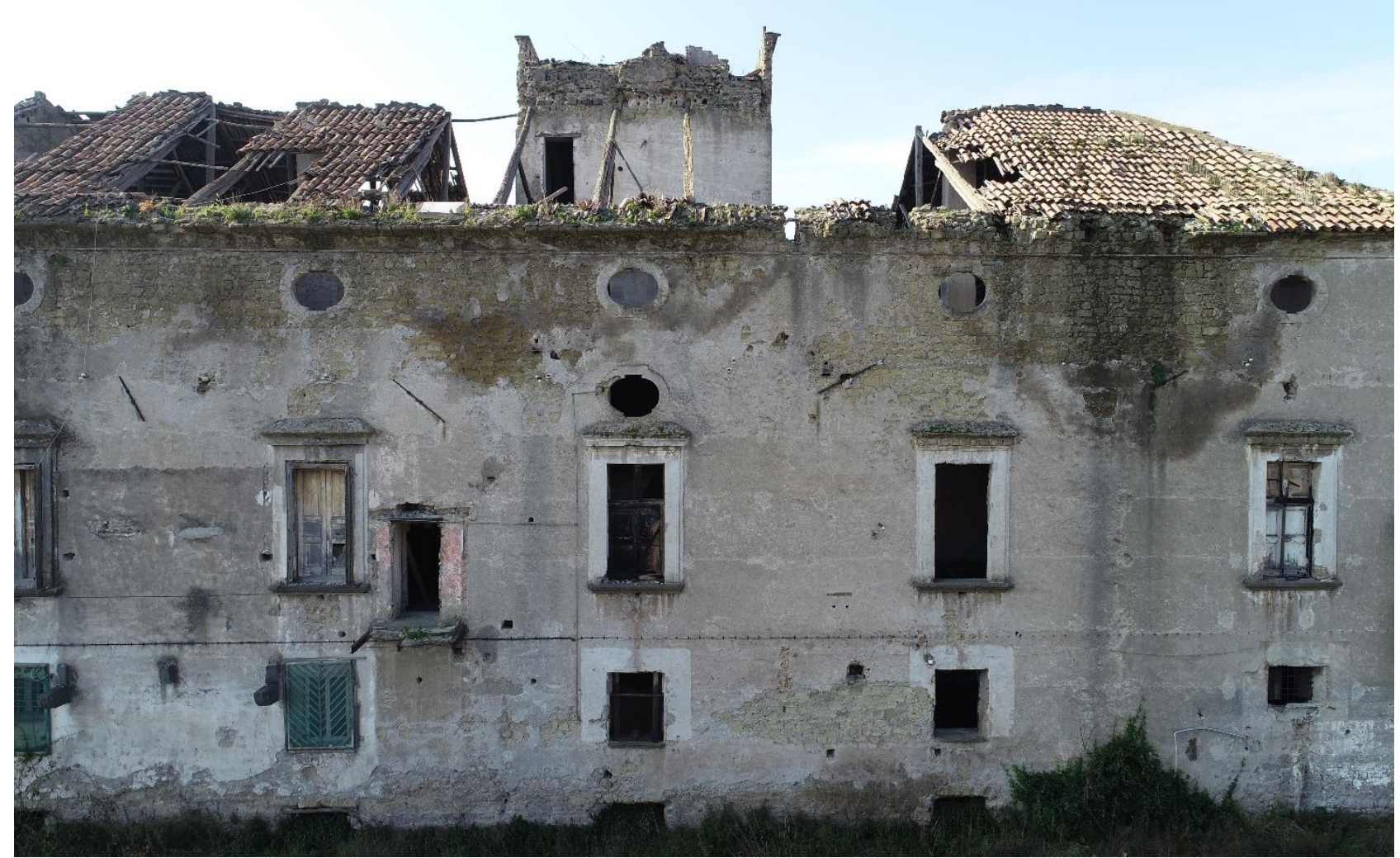

Figure 7. The facade facing Vesuvius (M. Facchini, 2020).

stratigraphic reading is more complex. It certainly represents the oldest part of the factory, and the one that has undergone the greatest transformations. Today it consists of a double row of rooms, partly covered with vaults and better preserved, partly with wooden floors, almost all collapsed or in a poor state of conservation. The study and analysis of the masonry completed leads us to believe that the more external environments, which today configure the facade towards the outside of the aforementioned building, were built later than the internal ones and have been remodeled several times also in recent times. Therefore, originally this building was made up of a single series of volumes, highly altimetrically articulated.
In the center of the building was the entrance hall which allowed access to the courtyard; to its left, there were three or four onelevel rooms intended for storage. On the other side, however, with access from the entrance hall, there are the cellars, at about $2.50 \mathrm{ml}$, below the level of the courtyard. It comes from the oldest and most fascinating rooms of the villa, intended for the processing and aging of wine. Going down a ramp of about twenty steps, a covered area with a barrel vault, marked between arches, was used for the pressing of the grapes. On the left, in fact, there is a large two-screw wooden press connected through stone canals to two thyme places in a neighboring room where the wine produced was stored, before transferring it to the barrels 

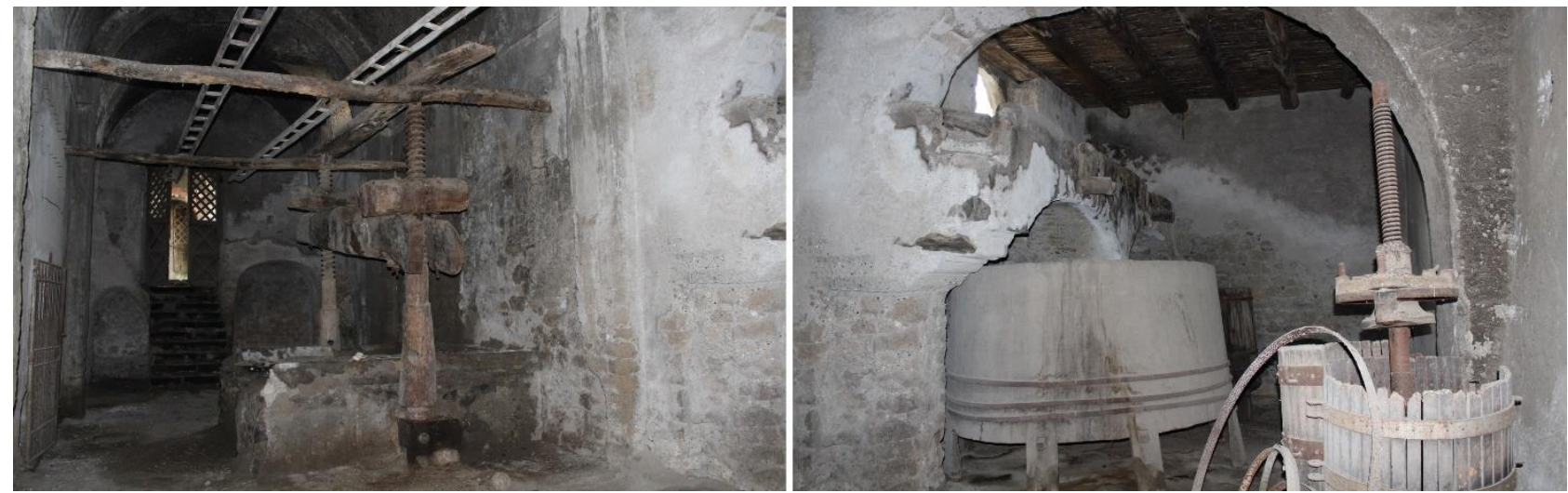

Figure 8 . The cellar with the ancient machinery for squeezing grapes.

for seasoning. From an opening at the bottom of this room another room, always covered with a vault, intended for the storage of the barrels. This environment, which develops perpendicularly to the first, is part of the third building block that closes the ' $U$ ' shape of the building on the north-east front. This last block has different levels: a ground floor with rooms used as deposits, accessible from the courtyard, a mezzanine floor, reached by climbing the external staircase in Vesuvian stone blocks, the first floor, the real home, served by an elegant staircase at three rampant which starts from the entrance hall and, finally, the attic, also used for the shelter of agricultural products, with access from a stairwell placed behind the main staircase. The first floor used as a residence consists of multiple rooms, some of which still bear the signs of 'wrapped' on the intrados of the wooden floors, subsequently covered by decorated false ceilings, some of which have been lost. The articulation of the elevations reflects the different intended use of the buildings: the only building block intended for residence has finely decorated frames and protrusions, elliptical openings of the seventeenth and eighteenth-century mold and a characteristic jutting brick structure, similar to a sentry box, at the right end of the north-east elevation. The elevations along the south-east and south-west sides more denounce the functional character of the complex and do not have decorations or ornaments.

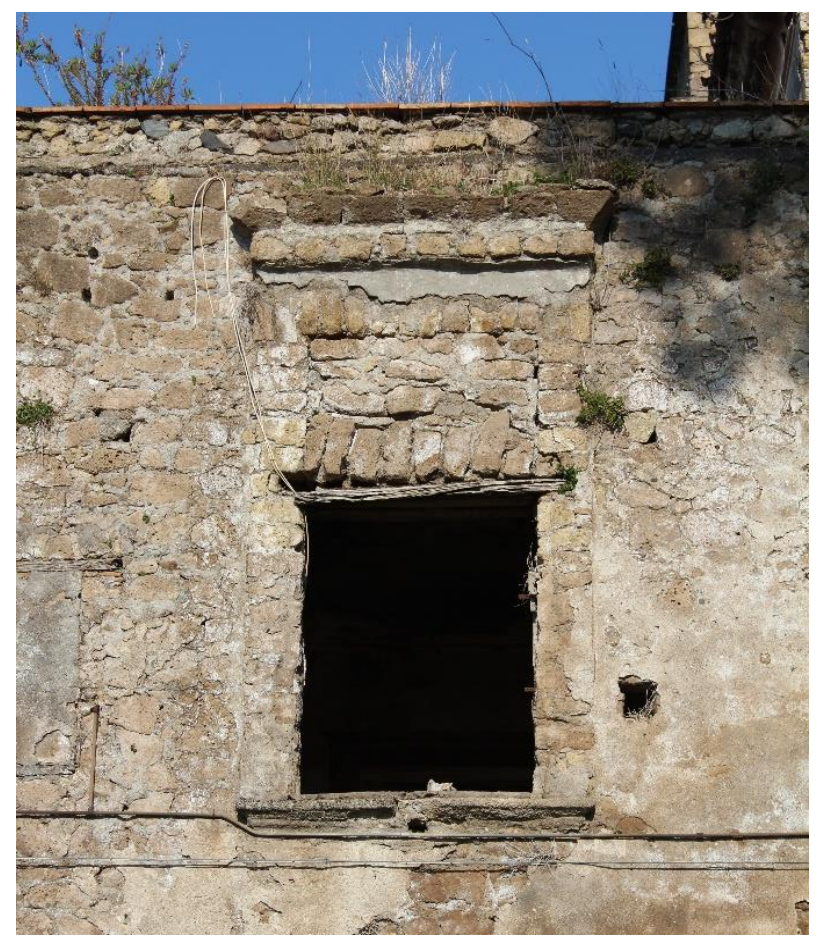

Figure 9. Detail of the south-east.

\section{TECHNIQUES AND DISTRIBUTION ASPECTS}

The complex articulation of the volumes, which can be found today in the architectural structure of Masseria Rota, clearly constitutes the outcome of numerous campaigns to transform the masseria which - for subsequent aggregations - have defined the current configuration. The almost total absence of archival documentation does not allow an exhaustive chronology of transformations that can only be hypothesized through direct analysis of the building. The mensiochronology applied to the walls of the factory - largely visible, because they are no longer plastered - allows to hypothesize the possible construction phases that have affected above all the risers, where it is easier to appreciate significant differences between the types of materials and the wall fixtures 'present (Picone, Veronese, 2019). Most of the perimeter and thorn walls of the villa are made of Neapolitan yellow tuff blocks mixed with volcanic lava stones (ignimbrite). In the main body of the farm and in the south-east wing, the blocks are square and uniform, arranged in regular rows and with a staggering of the joints halfway along the length of the block. This type, which also characterizes the chapel, is attributable to pre-eighteenth-century construction techniques, and would seem to belong to the original layout of the masseria. Although it is not possible to accurately establish the period of construction of the rooms, in fact, the presence of an Lshaped underground floor, which runs along the north-east side of the square and half of the south side. east, would suggest a unity of conception supported also by the presence of identical masonry appliances in the risers. This continuity is interrupted in the second half of the south-east side of the courtyard, then resumed in the walls of the small chapel, which could be coeval with the main building. In other rooms of the villa, and in particular along the south-west side, there is a masonry with rectangular and wedgeshaped tuff elements, alternating with less regular ashlars arranged in uncertain work that suggests subsequent aggregations, also because these walls are not always amortized on the walls described above. Through thermographic investigations, in particular, it was evident that even the L-shaped body belonging to the supposed initial layout of the masseria was not homogeneous; the south-east side, in fact, originally appeared on a single terraced floor and only later was it raised with perimeter walls that were not clamped to the main facade of the body to the north east. Further wall connections are evidently attributable to twentieth-century integration and restoration (Aveta, 1987). Even the horizontal partitions of the farm are not homogeneous. The masonry vaults, present in the underground rooms and in almost all the rooms on the ground floor of the courtyard, are of the 'barrel' or 'sail' type and were built with tuff ashlars. The wooden floors - present, however, largely in the building block to the north-east - are made up of rough-hewn chestnut main beams, simply resting on the ends and rough transverse beams ('panconcelle'), with overhanging boulder formed by lapillus, pumice stones and common mortar. The 


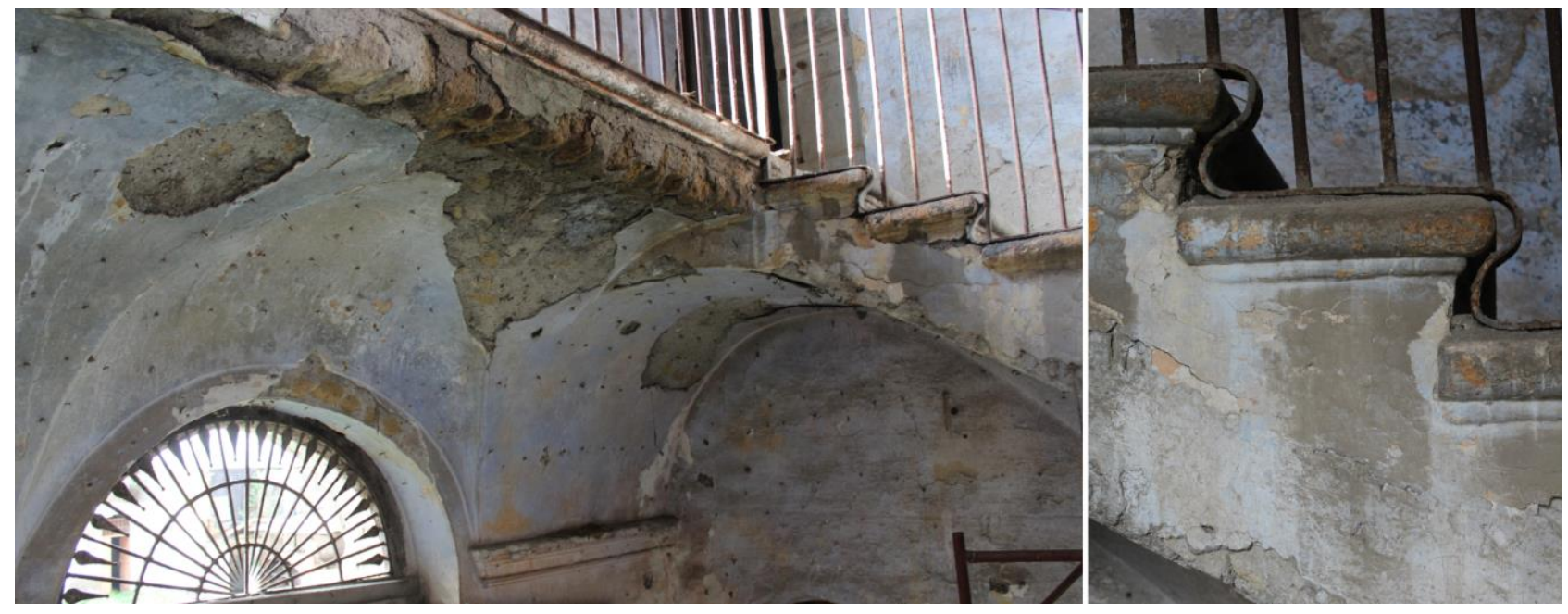

Figure 10. Details of the access staircase to the main floor.
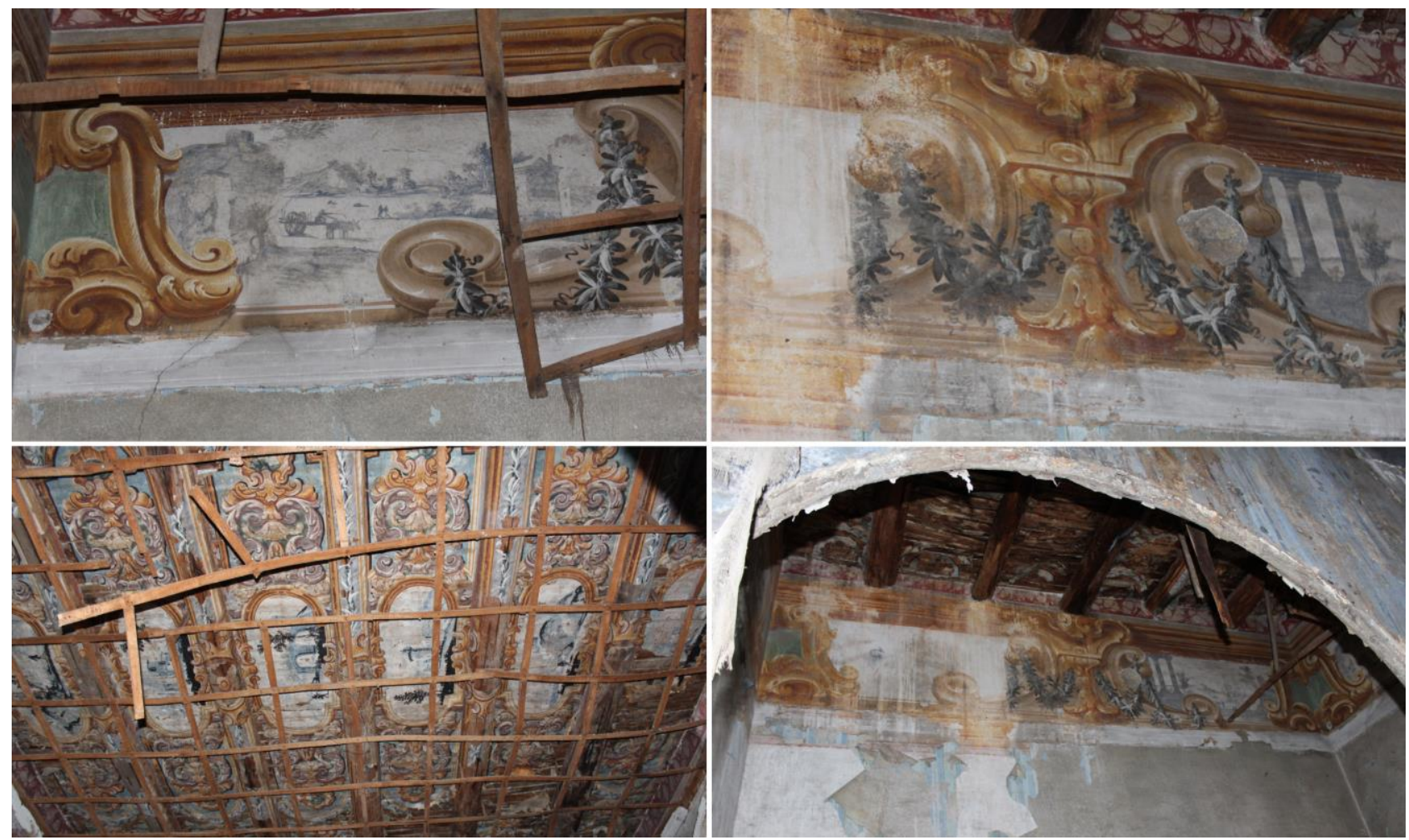

Figure 11. Details of the 18th-century parietal decorations and 'incartate' that covered the wooden

floors of the main floor, later covered by ceilings as part of 19th-century modernization.

coverage of this body is with inclined double-pitched wooden structures. The main beams consist of trusses with brackets and monks resting on the perimeter masonry, with the exception of the central part, where in correspondence with the top tower, the roof is supported by just struts. Above the trusses rest the purlins with a wheelbase of about $70 \mathrm{~cm}$ and then the strips on which the flat Roman tiles are placed. The large frame is in chestnut wood while the strips are in fir wood. An evident trace below the current ridge clearly suggests a different roof line that in the past had a milder slope. The presence of two wells, one in the internal courtyard, one along the south-east facade of the masseria, should be underlined. The absence of a superficial aquifer for the entire Vesuvius foothills overlooking the coast line has always been a problem for farmers in the area. To remedy this difficulty, since Roman times, the inhabitants of the Vesuvian areas built large underground tanks for the collection and conservation of rainwater, usually accessible from inside the farms through special wells. Very often the different tanks were connected to each other and placed in succession along a slope. This allowed, once the cistern further upstream was filled, that the water, beyond the ridge line, was directed through a special conduit to the cistern further downstream, and so on. Finally, difficult to interpret are some piperno shelves that protrude along the north east and south east elevation of the villa. Placed at the same altitude, they would suggest the existence of balconies, or perhaps of a walkway, along the entire elevated perimeter of the original complex. The presence of these elements, typical of the architecture of the Neapolitan area between the fifteenth and sixteenth centuries, would suggest a foundation of the villa much earlier than the first eighteenth-century representations, although there is no further evidence of the presence of the complex already in the Renaissance period (Picone, Russo, 2017). 


\section{RESTORATION AND ENHANCEMENT STRATEGIES}

Given the variety of issues just described, masseria Rota is a tangible testimony not only of the construction art in the Vesuvian area, but also of the social history of a vast territory with recurring specificities, as well as the history of families and power groups of Neapolitan society since the eighteenth century. The morphological complexity of Masseria Rota, the use of techniques and materials, its role of 'material testimony having the value of civilization' once again demonstrates how vernacular architecture, like courtly and 'monumental' architecture, represents a heritage to protect and pass on to the future. Almost a century after the first pioneering studies on rural architecture, such as the communication of Edwin Cerio at the 1922 Capri Landscape Conference, the thesis of Roberto Pane of the same year and the exhibition curated in Milan by Giuseppe Pagano and Guarniero Daniel in 1936, the protection of that building called 'minor' has now assumed an important role also in current legislative instruments and in the activity of the institutions responsible for the conservation of cultural heritage (Cerio, 1923; Pane, 1928; Pagano, Daniel, 1936). However, the 'poor' character of these architectures, their intended use, in many cases still linked to functional needs and the production cycle of the earth, the isolated and closed position, still leads to implement interventions that are not properly respectful of the pre-existence and speculative, especially if one considers that most of these artifacts are privately owned. In fact, the owners do not always have the resources to consider culturally and technically prudent conservative interventions and, even in cases where there is the support of the protection bodies, as in the case of Masseria Rota, the intervention, when there is, comes down to heavy steel supports and extensive use of reinforced concrete (Picone, 2015). The current state of abandonment of Masseria Rota is determined, as in most of the historic farms in the Vesuvian area, by the impossibility of carrying out the conservative interventions imposed by the superintendency, also due to a certain reticence to hypothesize for the new building receptive, cultural or leisure functions in an area where "doing business" is not always easy. Currently the most significant forms of instability and degradation for the building are mainly due to the long condition of abandonment and the collapse of the roofs in several parts of the complex. Most of the floors between floors, also due to the action of atmospheric agents and the stagnation of rainwater, show evident depressions in the load-bearing structure, sagging at the supports and in many cases even collapses. This condition also caused significant damage to the entire decorative body of the residential body which had decorated wrapping - although hidden by false ceilings belonging to subsequent renovations of the apartment - and wall paintings, with bucolic scenes and landscapes. The huge presence of moisture, due to the lack of coverage, has further reduced the load-bearing capacity of the woods exposed to the elements, also favoring the attack of xylophagous insects and fungi. The lack of the roof at many points of the multi-level body of the farm has also led to a significant rotation of the facades, which, no longer contained by the resistant action of the roofing chains and the main beams of the floors, have strong "off-lead" features. To contain the possible overturning, also visible from the lesions present in the wall connections between the facades of the building and the spine walls, there are steel chains already inserted in the masonry in the past, when this phenomenon must have already caused minor failures. Finally, small vertical lesions beneath the beams of the floors demonstrate the lack of bearings or curbs and the age of the walls. This picture of instability and degradation can be found in many similar historic farms in the area and is largely due to the same causes. The definition of an intervention program with common conservation objectives, in compliance with the specificities of each individual building, would be desirable in order to transmit to the future the material and non-material values of which the system of these rural architectures is the bearer. However, even more important is the definition of integrated conservation strategies that involve local institutions and associations and owners in order to identify lines of development that through the restoration, reuse and "networking" of the abandoned historic farms of the Vesuvian area can increase the attractiveness of the territories in respect of individual cultural specificities and common growth potential.

\section{REFERENCES}

Amore R., 2017: Il Real sito di Portici, tra tutela $e$ valorizzazione, in La Baia di Napoli. Strategie integrate per la conservazione. ArtStudioPaparo, Napoli, pp. 376-384.

Atlante geografico del Regno di Napoli delineato per ordine di Ferdinando (...) 1808. Napoli, s.n., 1788-1812.

Aveta, A.,1987: Materiali e tecniche tradizionali nel napoletano. Note per il restauro architettonico, Arte Tipografica Ed., Napoli

Cerio, E., 1923: La protezione dell'architettura e del paesaggio, in Il Convegno del Paesaggio, Napoli, pp. 88 ss.

De Seta, C., Di Mauro, L., Perone, M., 1980: Ville Vesuviane, Milano, Rusconi.

De Simone, A., Aoyagi, M., 2010: Il thiasos marino dalla villa di somma vesuviana, in Atti del $X$ Congresso internazionale dell'AIPMA. Napoli 17-21 settembre 2007, edit by di Irene Bragantini, Università degli Studi di Napoli «L'Orientale», Napoli, Vol. II, pp. 573-593.

De Simone, G., Lubrano, M., Torino, De Luca, A., Perrotta, A., Scarpati, C., 2012: La villa con terme di Pollena Trocchia in località Masseria De Carolis: architettura, abitanti, eruzioni, in Annali 2011-2012, Archeologia. Studi e ricerche sul campo, Università degli Studi Suor Orsola Benincasa, Napoli, pp. 195-217.

De Simone, G., Perrotta, A., Scarpati, C., 2013. L'eruzione del 472 d.C. ed il suo impatto su alcuni siti alle Falde del Vesuvio, in Rivista di Studi pompeiani, XXII, 2011, L'Erma di Bretshneider, Roma, pp. 61-71.

Soricelli G., 2001: La regione vesuviana tra secondo e sesto secolo d.C., in Modalità insediative e strutture agrarie nell'Italia meridionale in età romana, edit by Lo Cascio E. e Storchi Marino A., Edipuglia, Bari, pp. 455-472.

Pagano, G., Daniel, G., 1936: Architettura rurale italiana, Milano

Pane, R., 1928: Tipi di architettura rustica in Napoli e nei Campi Flegrei, in «Architettura e Arti Decorative», VII, 12, pp. 529-543

Picone, R. 2015: Vernacular architecture in Campania Felix. Values and conservation problems, Vernacular Architecture: Towards a Sustainable Future, pp. 625-630, Taylor \& Francis Group, London.

Picone, R., Russo, V., 2017, edit by: L'arte del costruire in Campania tra restauro e sicurezza strutturale, edit by R. Picone and V. Russo, CLEAN, Napoli

Picone, R., Veronese L., 2019: Specifity of historical buildings and Bim methodologies. A first experimentation for the Federico II headquarters in Naples. The Int, Arch. of the Photogrammetry, Remote Sensing and Spatial Inf. Sciences, Volume XLII-2/W11.

Marino, B.G., 2019: Accross the Stones, Immagini, paesaggi e memoria. La conoscenza interdisciplinare per la conservazione e la valorizzazione della Fortezza del Girifalco, editing by Editori Paparo, Roma 